УДК 633.31/37: 631.95: 631.811.98: 581.132, DOI 10.31210/visnyk2018.04.07

(C) 2018

Карпенко В. П., доктор сільськогосподарських наук, Коробко О. О., аспірант

(науковий керівник - доктор сільськогосподарських наук В. П. Карпенко)

Уманський національний університет садівництва

\title{
ВПЛИВ ГЕРБІЦИДУ І БІОЛОГІЧНИХ ПРЕПАРАТІВ НА ЗАБУР'ЯНЕНІСТЬ І ГУСТОТУ ПОСІВІВ НУТУ
}

\section{Рецензент - доктор сільськогосподарських наук В. Я. Білоножко}

Наведено результати досліджень стосовно впливу гербіииду «Панда», регулятора росту рослин «Стимпо» і мікробного препарату «Ризобофіт» на забур'яненість та густоту посівів нуту сорту Пам'ять в умовах Правобережного Лісостепу Украӥни.

Встановлено взаємозв'язок між дією різних норм гербіциду «Панда» $і$ біологічних препаратів на видовий, кількісний склад бур'янів та густоту культурних рослин у посівах нуту. Відзначено дію гербіциду як ефективного заходу боротьби із сегетальною рослинністю в нормах 3,0-4,0 л/га. Досліджено, щуо найменша кількість і маса бур'янів у посівах, без значного зниження щүільності рослин нуту, відзначалися $у$ варіантах за поєднаного використання трунтового гербіициу «Панда» в нормах 3,0-4,0 л/га, регулятора росту рослин «Стимпо» $(0,025 \mathrm{r} / \mathrm{m})$ та мікробного nрепарату «Ризобофіт» $(1,0 \mathrm{r} / \mathrm{m})$. Сумісна дія гербіциду з біологічними препаратами у даних варіантах досліду забезпечила зниження забур'яненості посівів за кількістю проти контролю I на 76-85\%. При циьому густота рослин у посіві знизилася лише на 2-3\%.

На основі проведених досліджень встановлено найефективнішу комбінацію використання препаратів, щзо забезпечує підвищення продуктивності посівів, зниження їх забур'янення та є екологічно безпечною для навколишнього середовища.

Ключові слова: нут, гербіцид, регулятор росту рослин, мікробний препарат, забур'яненість, кількість і маса бур'янів, густота посівів.

Постановка проблеми. У підвищенні загального рівня і якості білкового харчування населення зернобобові культури займають провідне місце. За поживністю і різноманіттям використання на харчові цілі серед зернобобових культур особливо виділяється нут. Проте його посіви мають низьку конкурентну спроможність щодо бур'янів, зокрема у першій половині вегетаційного періоду. Наявність бур'янів у посівах нуту суттєво впливає як на продуктивність, так і на якість урожаю. Тому ретельне знищення їх у посівах нуту - одна з важливих умов отримання високих врожаїв. У більшості випадків у технології вирощування нуту виправданим є застосування гербіцидів [13].
Однак за обробки гербіцидами рослини нуту піддаються стресу, наслідком якого може бути порушення як фотосинтетичних, так і азотфіксувальних процесів. Тому для зняття негативного впливу токсичних препаратів на рослини нуту доцільним $\epsilon$ застосування у технологіях вирощування культури регуляторів росту рослин природного походження та мікробних препаратів [13].

Аналіз основних досліджень і публікацій, у яких започатковано розв'язання проблеми. Інноваційним напрямом захисту посівів культурних рослин від бур'янів $є$ ефективне регулювання їх чисельності за одночасного зниження пестицидного навантаження на агрофітоценози. На думку вчених [12], якщо втрати врожаю через засміченість полів оцінюються в 10-15\%, то стрес, викликаний гербіцидами, навіть незважаючи на позитивні наслідки знищення бур'янів [2], може призводити до зниження врожаю до $50 \%$. У даний час хімічні антидоти для гербіцидів використовуються недостатньо широко і ефективно, оскільки більшість із них мають вузьку специфіку дії. Зважаючи на це, актуальним $\epsilon$ пошук різних нових прийомів і засобів, які б забезпечували зниження негативного впливу гербіциду на рослини.

Підбір ефективних бакових сумішей гербіцидів із біологічно активними речовинами під різні види рослин $є$ одним із актуальних напрямів вирощування високопродуктивних посівів. Проблема застосування гербіцидів у бакових сумішах 3 іншими речовинами у посівах нуту досліджувалася як вітчизняними, так і закордонними вченими, зокрема їх дослідження були зосереджені на визначенні специфіки забур'янення посівів $[4,8,9,11,21,22]$, проходженні в рослинах фізіологічних процесів $[17,19,20]$, однак комплексна дія гербіцидів і біологічних препаратів на забур'яненість і густоту посівів нуту практично не вивчалася.

Мета досліджень - розробити і обгрунтувати ефективні заходи боротьби з бур'янистою рос- 


\section{СІЛЬСЬКЕ ГОСПОДАРСТВО. РОСЛИННИЦТВО}

линністю у посівах нуту, за яких продуктивність посівів не знижується.

Завдання дослідження: встановити оптимальні норми застосування гербіциду «Панда»в комплексі з біологічними препаратами - регулятором росту рослин «Стимпо» i мікробним препаратом «Ризобофіт», за яких досягається максимально можливе знищення бур'янистої рослинності, а негативна дія на культурні рослини гербіциду мінімалізується.

Матеріали і методики досліджень. Експериментальну частину роботи виконано упродовж 2015-2017 рр. у польових умовах навчально-виробничого відділу та науково-дослідної лабораторії кафедри мікробіології, біохімії i фізіології рослин Уманського національного університету садівництва. Схема досліду включала варіанти з використанням гербіциду «Панда» в нормах 3,$0 ; 4,0 ; 5,0 ; 6,0$ л/га (діюча речовина - пендиметалін [14]) окремо і по фону обробки насіння регулятором росту рослин (РРP) «Стимпо» у нормі 0,025 л/т (комплекс біологічно-активних сполук [16]), мікробним препаратом (МБП) «Ризобофіт» 1,0 л/т (бактерії родини Rhizobiacea штаму ST 282 [15]) та сумішшю РРР Стимпо і МБП «Ризобофіт» у тих же нормах у посівах нуту сорту Пам'ять $[1,5]$. Детальну схему досліду наведено в таблицях. Площа облікової ділянки становила 42 м², повторення досліду - триразове 3 систематичним розміщенням варіантів. Фактор А - вплив гербіциду «Панда» в різних нормах (3,0-6,0 л/га), Фактор Б - вплив біологічних препаратів.

Основні показники в дослідах визначали згідно 3 методиками обліку забур'яненості та густоти посівів [3, 18]. Статистичну обробку результатів досліджень проводили за методами дисперсійного аналізу, описаними Б. А. Доспєховим [6].

Результати досліджень. Встановлено, що в роки досліджень у посіві нуту формувався змішаний тип забур'яненості з перевагою однорічних злакових видів. Найбільш розповсюдженими бур'янами були: мишій сизий (Setaria glauca (L.) Pal. Beauv.) та куряче просо (Echinochloa crussgalli (L.) Pal. Beauv.), з дводольних - лобода біла (Chenopodium album L.), щириця звичайна (Amaranthus retroflexus L.), гірчак розлогий (Poligonum scabrum Moench.), редька дика (Raphanus raphanistrum), осот рожевий (Cirsium arvense (L.) Scop.) й інші види.

Результати обліку забур'яненості наведено у табл. 1 і 2.

Вони показали, що кількість і маса бур'янів у посіві нуту варіювали як за роками, так і в залежності від використання різних норм гербіциду
Панда, внесених окремо та на фоні обробки насіння РРР «Стимпо» і МБП «Ризобофіт». Так, за дії гербіциду «Панда» в нормах 3,$0 ; 4,0 ; 5,0 ; 6,0$ л/га кількість бур'янів у 2015 р становила 38,4; 24,$5 ; 12,5$ і 10,2 шт./м²; за внесення гербіциду в таких же нормах на фоні використання регулятора росту рослин «Стимпо» $(0,025$ л/т) - 26,2; 19,8; 11,6; 9,8 шт./м² відповідно, а на фоні використання мікробного препарату «Ризобофіт» $(1,0$ л/т) - 31,5; 20,4; 11,9; 9,2 шт./м². За комплексного використання регулятора росту рослин «Стимпо» $(0,025$ л/т) 3 мікробним препаратом «Ризобофіт» $(1,0$ л/т) та внесення по даному фону гербіциду «Панда» в нормах 3,0; 4,0; 5,0; 6,0 л/га кількість бур'янів у посіві нуту становила 25,2; 16,5; 10,6 і 19,5 при 105,6 шт./м² у варіанті без застосування препаратів (контроль I). Аналогічна залежність із формуванням забур'яненості посіву нуту простежувалася і в 2016 та 2017 роках. Однак, найнижчою вона була у варіантах досліду у 2017 р. Так, у варіанті без застосування біологічних препаратів та гербіциду (контроль I) кількість бур'янів у 2015 р. склала 105,6 шт./м², у той же час у 2016 і 2017 pp. їх кількість становила 100,8 і 96,1 шт./м² відповідно, що узгоджуються 3 показниками погодних умов, зокрема вологозабезпеченості.

У середньому за три роки досліджень за самостійної дії МПБ «Ризобофіт» спостерігалося зростання забур'яненості посівів нуту відносно контролю I (табл. 1) на 31 \%, маси бур'янів (табл. 2) на $51 \%$. За дії РРР «Стимпо» $(0,025$ л/т) кількість бур'янів збільшувалась до контролю I на $18 \%$, але водночас їх маса відносно контролю I дещо знижувалася (на 7 \%).

У варіантах сумісного застосування МПБ Ризобофіт (1,0 л/т) і PРP «Стимпо» (0,025 л/т) забур'яненість відносно контролю I зросла в середньому за роки на $10 \%$, а маса зросла на $6 \%$.

Дія гербіциду «Панда» на забур'янення посіву нуту залежала від норми внесення препарату. Так, за норм внесення 3,0-4,0 л/га забур'янення посіву відносно контролю I зменшувалось в середньому на 63-76 \%, а маса бур'янів - на 68$78 \%$ відповідно.

За норм внесення гербіциду 5,0-6,0 л/га забур'янення відносно контролю I зменшувалась на 88-90\%, маса - 90-96\%. Проте разом із зростанням ефективності дії гербіциду спостерігалося зменшення густоти рослин нуту (рис. 1).

1. Без використання препаратів (контроль I);

2. Без використання препаратів + ручні прополювання упродовж вегетації (контроль II);

3. МБП «Ризобофіт» 1,0 л/т;

4. РРР «Стимпо» 0,025 л/т; 
5. МБП «Ризобофіт» 1,0 л/т + РРР «Стимпо» $0,025 \pi / \mathrm{T} ;$

6. «Панда» 3,0 л/га;

7. «Панда» 3,0 л/га, МБП «Ризобофіт» 1,0 л/т;

8. «Панда» 3,0 л/га, РРР «Стимпо» 0,025 л/т;

9. «Панда» 3,0 л/га, МБП «Ризобофіт» 1,0 л/т + РРP «Стимпо» 0,025 л/т;

10. «Панда» 4,0 л/га;

11. «Панда» 4,0 л/га, МБП «Ризобофіт» 1,0 л/т;

12. «Панда» 4,0 л/га, РРР «Стимпо» 0,025 л/т;

13. «Панда» 4,0 л/га, МБП «Ризобофіт» 1,0 л/т + PРP «Стимпо» 0,025 л/т;

14. «Панда» 5,0 л/га;
15. «Панда» 5,0 л/га, МБП «Ризобофіт» 1,0 л/т;

16. «Панда» 5,0 л/га, РРР «Стимпо» 0,025 л/т;

17. «Панда» 5,0 л/га, МБП «Ризобофіт» 1,0 л/т + РРР «Стимпо» 0,025 л/т;

18. «Панда» 6,0 л/га;

19. «Панда» 6,0 л/га, МБП «Ризобофіт» 1,0 л/т;

20. «Панда» 6,0 л/га, РРР «Стимпо» 0,025 л/т;

21. «Панда» 6,0 л/га, МБП «Ризобофіт» 1,0 л/т + РРР «Стимпо» 0,025 л/т.

Так, за дії гербіциду «Панда» в нормах 5,0-6,0 л/га вона в середньому за роки досліджень становила 46-43 рослини/м² відповідно, у той час як на контрольній ділянці I - 58 рослин/ $\mathrm{M}^{2}$.

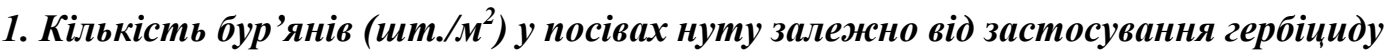 «Панда», РРР «Стимпо» і МБП «Ризобофіт» (фаза цвітіння)}

\begin{tabular}{|c|c|c|c|c|c|}
\hline $\begin{array}{l}\text { Гербіцид, } \\
\text { Фактор А }\end{array}$ & $\begin{array}{c}\text { Біологічно активні речовини, } \\
\text { Фактор В }\end{array}$ & $\begin{array}{l}\dot{a} \\
\dot{n} \\
\dot{n}\end{array}$ & $\begin{array}{l}\dot{a} \\
\dot{0} \\
\dot{d}\end{array}$ & $\frac{\dot{a}}{\stackrel{i}{a}}$ & $\begin{array}{l}\text { У серед- } \\
\text { ньому за } \\
\text { три роки }\end{array}$ \\
\hline \multirow{5}{*}{$\begin{array}{c}\text { Без } \\
\text { гербіциду }\end{array}$} & без біологічних препаратів (контроль I) & 105,6 & 100,8 & 96,1 & 100,8 \\
\hline & $\begin{array}{c}\text { без біологічних препаратів + ручні прополю- } \\
\text { вання впродовж вегетації (контроль II) }\end{array}$ & 0 & 0 & 0 & 0 \\
\hline & МБП «Ризобофіт», 1,0 л/т & 135,6 & 131,8 & 128,0 & 131,8 \\
\hline & РРР «Стимпо», 0,025 л/т & 120,5 & 119,3 & 118,0 & 119,3 \\
\hline & $\begin{array}{c}\text { МБП «Ризобофіт», } 1,0 \text { л/т + } \\
\text { РРР «Стимпо», 0,025 л/т }\end{array}$ & 115,1 & 111,1 & 106,2 & 110,8 \\
\hline \multirow{4}{*}{$\begin{array}{c}\text { Гербіцид } \\
\text { «Панда», } \\
\text { 3,0 л/га }\end{array}$} & без біологічних препаратів & 38,4 & 37,3 & 36,2 & 37,3 \\
\hline & МБП «Ризобофіт», 1,0 л/т & 31,5 & 28,2 & 22,9 & 27,5 \\
\hline & РРР «Стимпо», 0,025 л/т & 26,2 & 28,3 & 22,6 & 25,7 \\
\hline & $\begin{array}{c}\text { МБП «Ризобофіт», } 1,0 \text { л/т + } \\
\text { РРР «Стимпо», 0,025 л/т }\end{array}$ & 25,2 & 24,9 & 21,6 & 23,9 \\
\hline \multirow{4}{*}{$\begin{array}{c}\text { Гербіцид } \\
\text { «Панда», } \\
\text { 4,0 л/га }\end{array}$} & без біологічних препаратів & 24,5 & 24,8 & 22,1 & 23,8 \\
\hline & МБП «Ризобофіт», 1,0 л/т & 20,4 & 16,4 & 19,4 & 18,7 \\
\hline & РРР «Стимпо», 0,025 л/т & 19,8 & 16,3 & 12,8 & 16,3 \\
\hline & $\begin{array}{c}\text { МБП «Ризобофіт», } 1,0 \text { л/т + PРP } \\
\text { «Стимпо», } 0,025 \pi / \mathrm{T}\end{array}$ & 16,5 & 15,6 & 14,5 & 15,5 \\
\hline \multirow{4}{*}{$\begin{array}{c}\text { Гербіцид } \\
\text { «Панда», } \\
\text { 5,0 л/га }\end{array}$} & без біологічних препаратів & 12,5 & 12,3 & 10,4 & 11,7 \\
\hline & МБП «Ризобофіт», 1,0 л/т & 11,9 & 11,5 & 10,0 & 11,1 \\
\hline & РРР «Стимпо», 0,025 л/т & 11,6 & 10,8 & 9,6 & 10,7 \\
\hline & $\begin{array}{c}\text { МБП «Ризобофіт», } 1,0 \text { л/т + } \\
\text { РРР «Стимпо», 0,025 л/т }\end{array}$ & 10,6 & 10,2 & 9,8 & 10,2 \\
\hline \multirow{5}{*}{$\begin{array}{c}\text { Гербіцид } \\
\text { «Панда», } \\
6,0 \text { л/га }\end{array}$} & без біологічних препаратів & 10,2 & 9,8 & 8,9 & 9,6 \\
\hline & МБП «Ризобофіт», 1,0 л/т & 9,2 & 10,1 & 9,8 & 9,7 \\
\hline & РРР «Стимпо», 0,025 л/т & 9,8 & 9,4 & 9,2 & 9,5 \\
\hline & $\begin{array}{c}\text { МБП «Ризобофіт», } 1,0 \text { л/т + } \\
\text { РРР «Стимпо», 0,025 л/т }\end{array}$ & 9,5 & 10,3 & 9,1 & 9,6 \\
\hline & $\mathrm{HIP}_{05}$ & 2,54 & 3,69 & 3,78 & \\
\hline
\end{tabular}


СІЛЬСЬКЕ ГОСПОДАРСТВО. РОСЛИННИЦТВО

2. Маса бур'янів $\left(2 / \mathrm{M}^{2}\right)$ у посівах нуту залежно від застосування гербіциду «Панда», РРР «Стимпо» і МБП «Ризобофіт» (фаза цвітіння)

\begin{tabular}{|c|c|c|c|c|c|}
\hline $\begin{array}{l}\text { Гербіцид, } \\
\text { Фактор А }\end{array}$ & $\begin{array}{c}\text { Біологічно активні речовини, } \\
\text { Фактор В }\end{array}$ & $\frac{\dot{a}}{\stackrel{n}{n}}$ & $\begin{array}{l}\dot{2} \\
\stackrel{0}{0} \\
\stackrel{2}{1}\end{array}$ & $\frac{\dot{2}}{\hat{n}}$ & $\begin{array}{l}\text { У серед- } \\
\text { ньому за } \\
\text { три роки }\end{array}$ \\
\hline \multirow{5}{*}{$\begin{array}{c}\text { Без } \\
\text { гербіциду }\end{array}$} & без біологічних препаратів (контроль I) & 324,5 & 323,0 & 321,4 & 323,0 \\
\hline & $\begin{array}{c}\text { без біологічних препаратів + ручні прополю- } \\
\text { вання впродовж вегетації (контроль II) }\end{array}$ & 0 & 0 & 0 & 0 \\
\hline & МБП «Ризобофіт», 1,0 л/т & 505,6 & 488,6 & 471,6 & 488,6 \\
\hline & РРР «Стимпо», 0,025 л/т & 305,6 & 298,6 & 301,6 & 301,9 \\
\hline & $\begin{array}{c}\text { МБП «Ризобофіт», } 1,0 \text { л/т + } \\
\text { РРР «Стимпо», 0,025 л/т }\end{array}$ & 350,2 & 341,9 & 333,5 & 341,9 \\
\hline \multirow{4}{*}{$\begin{array}{c}\text { Гербіцид } \\
\text { «анда», } \\
\text { 3,0 л/га }\end{array}$} & без біологічних препаратів & 104,6 & 107,0 & 99,3 & 103,6 \\
\hline & МБП «Ризобофіт», 1,0 л/т & 98,4 & 99,1 & 95,7 & 97,7 \\
\hline & РРР «Стимпо», 0,025 л/т & 98,0 & 95,8 & 92,9 & 95,6 \\
\hline & $\begin{array}{c}\text { МБП «Ризобофіт», } 1,0 \text { л/т + } \\
\text { РРР «Стимпо», 0,025 л/т }\end{array}$ & 82,5 & 80,8 & 79,4 & 80,9 \\
\hline \multirow{4}{*}{$\begin{array}{c}\text { Гербіцид } \\
\text { «анда», } \\
\text { 4,0 л/га }\end{array}$} & без біологічних препаратів & 72,8 & 71,5 & 70,2 & 71,5 \\
\hline & МБП «Ризобофіт», 1,0 л/т & 66,2 & 62,5 & 78,8 & 69,2 \\
\hline & РРР «Стимпо» 0,025 л/т & 75,8 & 67,6 & 62,4 & 68,6 \\
\hline & $\begin{array}{c}\text { МБП «Ризобофіт», } 1,0 \text { л/т + } \\
\text { РРР «Стимпо», 0,025 л/т }\end{array}$ & 48,4 & 50,2 & 45,9 & 48,2 \\
\hline \multirow{4}{*}{$\begin{array}{c}\text { Гербіцид } \\
\text { «анда», } \\
\text { 5,0 л/га }\end{array}$} & без біологічних препаратів & 32,4 & 36,0 & 29,6 & 32,7 \\
\hline & МБП «Ризобофіт», 1,0 л/т & 32,4 & 31,9 & 29,4 & 31,2 \\
\hline & РРP «Стимпо», 0,025 л/т & 28,8 & 29,1 & 26,6 & 28,2 \\
\hline & $\begin{array}{c}\text { МБП «Ризобофіт», } 1,0 \text { л/т + } \\
\text { РРР «Стимпо», 0,025 л/т }\end{array}$ & 28,6 & 26,1 & 23,5 & 26,1 \\
\hline \multirow{5}{*}{$\begin{array}{c}\text { Гербіцид } \\
\text { «анда», } \\
\text { 6,0 л/га }\end{array}$} & без біологічних препаратів & 15,2 & 12,9 & 11,6 & 13,2 \\
\hline & МБП «Ризобофіт», 1,0 л/т & 15,9 & 14,7 & 14,2 & 14,9 \\
\hline & РРР «Стимпо», 0,025 л/т & 14,5 & 13,4 & 13,2 & 13,7 \\
\hline & $\begin{array}{c}\text { МБП «Ризобофіт», } 1,0 \text { л/т + } \\
\text { РРР «Стимпо», 0,025 л/т }\end{array}$ & 13,5 & 12,2 & 10,0 & 11,9 \\
\hline & $\mathrm{HIP}_{05}$ & 4,54 & 3,69 & 3,78 & \\
\hline
\end{tabular}



Рис. 1. Густота рослин нуту залежно від дії гербіциду і біологічних препаратів, фази цвітіння, середнс за 2015-2017 рp. (HIP $2015=1,6 ; 2016=2,1 ; 2017=1,9)$ 


\section{СІЛЬСЬКЕ ГОСПОДАРСТВО. РОСЛИННИЦТВО}

За сумісної дії МБП «Ризобофіт» $(1,0$ л/т) та РPР «Стимпо» $(0,025$ л/т) і внесення по даному фону гербіциду «Панда» в нормах 3,0-4,0 л/га знищення кількості бур'янів у посіві нуту становило 76-85\%, а їх маса зменшувалась на 75$85 \%$ відповідно контролю І. При цьому густота рослин, у цих варіантах зменшувалась на $2 \%$ й $3 \%$. Така тенденція може свідчити про створення за дії даних комбінацій препаратів більш сприятливих умов для проходження в рослинах фізіолого-біохімічних процесів, обумовлених безпосередньою стимулюючою дією біопрепаратів, про що в своїх дослідженнях констатують $\mathrm{i}$ інші вчені $[7,10]$, за якої зростають біометричні показники рослин (маса, площа листя, висота) та підвищується конкурентна здатність культури.

За сумісного використання МБП «Ризобофіт» $(1,0$ л/т) і РРP «Стимпо» $(0,025$ л/т) та внесення наступних норм гербіциду «Панда» $(5,0$ та 6,0 л/га) кількість бур'янів у посіві нуту знижувалася на 89 та $90 \%$, їх маса - на 92-96\%. Однак густота рослин, за дії підвищених норм гер-

\section{БІБЛІОГРАФІЯ}

1. Видання Селекційно-генетичного інституту - Національного центру насіннєзнавства та сортовивчення (СГІ - НЦНС), ЗАТ «Селена». Одеса, 2011. - 128 c.

2. Германцева Н. И., Балашов А. В., Зотиков В. И. $u \partial p$. Ресурсосберегающая технология производства нута - М. : Росинформагротех, 2015. - 48 с.

3. Грииаєнко 3. М., Грииаєнко А. О., Карпенко В. П. Методи біологічних та агрохімічних досліджень рослин і грунтів. - К. : Нічлава, 2003. - 320 с.

4. Гутянський Р., Ільченко Н., Шелякіна Т., Посилаєва O. Урожайність і якість насіння гороху, нуту, сої за впливу забур'яненості, інокуляції та гербіциду. - Селекція і насінництво.- 2018, №113. $-179-188$.

5. Державний реєстр сортів рослин України . Державна ветеринарна та фітосанітарна служба України. - 2015. - URL: http://vet.gov.ua /sites/ default/ files/ReestrEU-2015-01-14a.pdf. (дата звернення: 20.07.2018).

6. Доспехов Б. А. Методика полевого опыта. - М. : Колос, 1973. - 335 c.

7. Задорожний В. С., Карасевич В. В., Мовчан I. В., Колодій С. В. Шкідливість бур'янів та їх контролювання в посівах нуту в умовах Правобережного Лісостепу України. // Наукові праці Інституту біоенергетичних культур і цукрових буряків. - 2014. Вип. 20. - С. 31-37.

8. Задорожній В. С., Карасевич В. В., Мовчан И. В. та інші. Способи контролю бур'янів в посівах сої в правобережному Лесостепі України // Корми і біциду, знижувалась відносно до контролю I на $13 \%$ і $24 \%$, що може свідчити про деяку негативну дію даних норм препарату на рослини нуту.

Висновок. Виконані дослідження засвідчили, що внесення грунтового гербіциду «Панда» $\epsilon$ ефективним заходом у зниженні забур'яненості посівів нуту як за кількість, так і за масою. Проте ефективність його дії підвищується на фоні використання біологічних препаратів для обробки насіння - РРР «Стимпо» та МБП «Ризобофіт», за яких значно покращуються біометричні показники рослин та зростає конкурентна здатність культури до бур'янів.

Найефективнішими за дією на рослини нуту i бур'яни виявилися норми гербіциду «Панда» $3,0-4,0$ л/га в комбінації з біологічними препаратами РРР «Стимпо» та МБП «Ризобофіт», за яких кількість і маса бур'янів знижуються на 76$85 \%$ і 75-86 \%, відповідно при цьому зниження густоти посіву нуту становить лише 2-3 \%.

кормовиробництво. - 2015. - Вип. 81. - С. 157163.

9. Каленська С. М., Новичька С. В., Нетупська I. Т. Формування врожаю нуту під впливом елементів вирощування // Вісн. держ. аграр. ака-демії. 2012. - № 2. - C. 21-25.

10. Карпенко В. П., Грицаєнко 3. М., Притуляк P. М. Біологічні основи інтегрованої дії гербіцидів і регуляторів росту рослин. - Умань, 2012. - $357 \mathrm{c}$.

11. Макух Я. П., Ременюк С. О., Сміх В. М. Специфіка процесів забур'янення посівів нуту // Наукові доповіді Національного університету біоресурсів і природокористування України. - 2017. - №1. $-65 \mathrm{c}$.

12. Неиветаев В. П., Правдин И. В., Петренко $A$. B. Урожайность сортов нута при использовании микробиологических препаратов // Достижения науки и техники АПК. - 2016. - Т. 30. - № 1. - С. 37-39.

13. Павленко В. П., Петров Н. Ю., Мельникова $A$. B. Технологии и средства возделывания нута. Волгоград: Волгоградская государственная сельскохозяйственная академия, 2003. - 160 c.

14. Панда, КЕ Каталог. URL https://ukravit. ua/uk/panda/ (дата звернення 10.06.2018).

15. Ризобофіт, КЕ Каталог. URL: http://www. znamagro.com.ua/ ua/ catalog/ bakterialnyie-udobreniya /rizobofit.html. (дата звернення: 20.07.2018).

16. Стимулятор росту Стимпо : Каталог. URL: http://www.agrobiotech. com.ua/ua/stimpo (дата звернення: 20.07.2018).

17. Ткаліч I., Бочевар O. Ефективність гербі- 
цидів у посівах нуту. Бюлетень Інституту сільського господарства степової зони НААН України. - 2015. - № 8. - С. 91-94.

18. Трибель С. О. та ін. Методики випробування і застосування пестицидів. - К. : Світ, 2001. - 448 с.

19. Erdal Elkoca, Faik Kantar, Sahin Fikrettin. Influence of Nitrogen Fixing and Phosphorus Solubilizing Bacteria on the Nodulation, Plant Growth, and Yield of Chickpea. - Journal of Plant Nutrition. - 2008. - 31. - 157-171.

\section{ANNOTATION}

Karpenko V. P., Korobko O. O. The impact of the herbicide and biologic preparations on the weediness and crop density of chickpea.

The article provides the results of the investigation of the impact of the herbicide «Panda», the plant growth regulator «Stympo» and the microbial preparation «Ryzobofit» on the weediness and crop density of chickpea of the breed Pamiat in the conditions of Right-Bank ForestSteppe of Ukraine.

We established the connection between the act of different limits of the herbicide «Panda», the plant growth regulator «Stympo» $(0.0251 / \mathrm{t})$ and the microbial preparation «Ryzobofit» $(1.01 / \mathrm{t})$, the quantitative content of weeds and the density of crop plants of chickpea. We determined the effective action of the herbicide against growing in grain fields in limits 3.0-4.0 1/ga.

It was investigated that the least amount and mass of weeds in crops, without substantial decrease of cheakpea density, was distinguished while
20 Hani Ghosheh, Moh'D El-Shatnawi. Influence of volunteer durum wheat (Triticum durum) cultivars and density on lentils (Lens culinaris). - Acta Agronomica Hungarica. - 2006. - 54. -101-108.

21. Shyam S. Yadav, Redden R. R., Chen W. Chickpea Breeding and Management. - CABI; First edition 2007. $-638 \mathrm{c}$.

22. Yadav, Shyam \& Redden, Robert \& Chen, $W$ \& Sharma, B. (2007). - Chickpea breeding and management. - CAB Int. - 538-554.

combining the soil herbicide «Panda» in limits 3.0$4.0 \mathrm{l} / \mathrm{ga}$, the plant growth regulator «Stympo» $(0.025 \mathrm{l} / \mathrm{t})$ and the microbial preparation «Ryzobofit» $(1.01 / \mathrm{t})$. The joint effect of the herbicide and the biological preparations in the given variants of the investigation provided the decrease of weediness of crops in the amount against the control I on $76-85 \%$. Moreover, the density of plants decreased only on $2-3 \%$.

On the base of the conducted experiments the most efficient combination of the usage of preparations was determined - the growth regulator «Stympo» $(0.0251 / \mathrm{t})$, the microbial preparation «Ryzobofit» $(1.0 \mathrm{l} / \mathrm{t})$ and the soil herbicide «Panda» in limits 3.0-4.0 1/ga, which provides the increase of crop productivity, decrease of their weediness and which is environmentally friendly.

Key words: chickpea, herbicide, plant growth regulator, microbial preparation, weediness, amount and mass of weeds, crop density. 